\title{
Cordonnier Grade 1 Viral Complication, Mucous Herpes Simplex Virus Infection
}

National Cancer Institute

\section{Source}

National Cancer Institute. Cordonnier Grade 1 Viral Complication, Mucous Herpes

Simplex Virus Infection. NCI Thesaurus. Code C138304.

Any mucous herpes simplex virus infection. 